\title{
KRAS Mutation in Small Cell Lung Carcinoma and Extrapulmonary Small Cell Cancer
}

\author{
Hilmi Kodaz ${ }^{1}$, Ebru Taştekin², Bülent Erdoğan ${ }^{1}$, İlhan Hacıbekiroğlu ${ }^{1}$, Hilmi Tozkır , Hakan Gürkan ${ }^{3}$, Esma Türkmen ${ }^{1}$, \\ Bora Demirkan ${ }^{3}$, Sernaz Uzunoğlü, İrfan Çiçin ${ }^{1}$
}

\begin{abstract}
${ }^{1}$ Department of Medical Oncology, Trakya University School of Medicine, Edirne, Turkey ${ }^{2}$ Department of Medical Pathology, Trakya University School of Medicine, Edirne, Turkey ${ }^{3}$ Department of Medical Genetics, Trakya University School of Medicine, Edirne, Turkey
\end{abstract}

Background: Lung cancer is one of the most lethal cancers. It is mainly classified into 2 groups: non-small cell lung cancer (NSCLC) and small cell lung cancer (SCLC). Extrapulmonary small cell carcinomas (EPSCC) are very rare. The Ras oncogene controls most of the cellular functions in the cell. Overall, $21.6 \%$ of human cancers contain a Kirsten Ras (KRAS) mutation. SCLC and EPSCC have several similar features but their clinical course is different.

Aims: We investigated the KRAS mutation status in SCLC and EPSCC.

Study design: Mutation research.

Methods: Thirty-seven SCLC and 15 EPSCC patients were included in the study. The pathological diagnoses were confirmed by a second pathologist. KRAS analysis was performed in our medical genetic department. DNA isolation was performed with primary tumor tissue using the QIAamp DNA FFPE Tissue kit (Qiagen; Hilden, Germany) in all patients. The therascreen KRAS Pyro Kit 24 V1 (Qia- gen; Hilden, Germany) was used for KRAS analyses.

Results: Thirty-four $(91.9 \%)$ of the SCLC patients were male, while $11(73.3 \%)$ of the EPSCC 1 patients were female. SCLC was more common in males, and EPSCC in females $(\mathrm{p}=0.001)$. A KRAS mutation was found in 6 $(16.2 \%)$ if SCLC patients. The most common mutation was Q61R (CAA $>$ CGA). Among the 15 EPSCC patients, 2 had a KRAS mutation (13.3\%). When KRAS mutant and wild type patients were compared in the SCLC group, no difference was found for overall survival $(\mathrm{p}=0.6)$.

Conclusion: In previous studies, the incidence of KRAS mutation in SCLC was $1-3 \%$; however, it was $16.2 \%$ in our study. Therefore, there may be ethnic and geographical differences in the KRAS mutations of SCLC. As a result, KRAS mutation should not be excluded in SCLC.

Keywords: Small cell lung cancer, extrapulmonary small cell carcinoma, KRAS mutation
Lung cancer is one of the most lethal cancers (1). The clinicopathological features of lung cancer are heterogeneous. It is classified into 2 groups as non-small cell lung cancer (NSCLC) and small cell lung cancer (SCLC). The genetic biomarkers are used to identify a targeted treatment in NSCLC $(2,3)$. Small cell lung cancer accounts for about $15-20 \%$ of all lung cancers, and is the most aggressive type $(4,5)$. The specific genetic alterations that take place in smallcell lung cancer development are still unclear (6). Extrapul- monary small cell carcinomas (EPSCCs) are very rare. The most frequently involved regions are the genitourinary and gastrointestinal systems (7). The Ras oncogene controls several cellular functions including cell proliferation, apoptosis, migration and differentiation (8). Kirsten RAS (KRAS) mutations are present in over $20 \%$ of all cancers (9). SCLC and EPSCC have several similar features but their clinical course is different $(10,11)$. Therefore, we investigated the KRAS mutation status in SCLC and EPSCC. 


\section{MATERIALS AND METHODS}

We retrospectively reviewed the records of patients diagnosed with SCLC and EPSCC between 2005 and 2014. This study was approved by the Institutional Review Board. Thirty-seven SCLC and 15 EPSCC patients were included in the study. We collected paraffin-embedded tissue blocks of patients from the archive of our pathology department. The pathological diagnoses were confirmed by the second pathologist.

KRAS analyses were performed in our certified medical genetics department. The KRAS mutations were studied: $\mathrm{CAA}>\mathrm{CTA}$ (Q61L), $\mathrm{CAA}>\mathrm{CAT}(\mathrm{Q} 61 \mathrm{H}), \mathrm{CAA}>\mathrm{CGA}(\mathrm{Q} 61 \mathrm{R}), \mathrm{GGT}>\mathrm{GTT}$ $(\mathrm{G} 12 \mathrm{~V}), \mathrm{GGC}>\mathrm{GAC}(\mathrm{G} 13 \mathrm{D}), \mathrm{GGT}>\mathrm{GAT}(\mathrm{G} 12 \mathrm{D}), \mathrm{GGT}>\mathrm{TGT}$ (G12C), GGT $>$ AGT (G12S), GGT $>$ GCT (G12A), GGT $>$ CGT (G12R), and GGT $>$ c.34_35GG $>$ TT (G12F). DNA isolation was performed with primary tumor tissue using the QIAamp DNA FFPE Tissue kit (Qiagen; Hilden, Germany) in all patients. The therascreen KRAS Pyro Kit 24 V1 (Qiagen; Hilden, Germany) was used for KRAS analyses. KRAS point mutations were analyzed with Pyro Mark Q24 software system (Qiagen; Hilden, Germany). This study was approved by the Institutional ethics board. Informed consent was obtained from all individual participants (or the legal representative) included in the study.

\section{Statistical analysis}

Statistical analysis was used for Statistical Package for the Social Sciences (SPSS) software version 18.0 (SPSS Corp.; Chicago, IL, USA). Overall survival was calculated from the date of diagnosis to the date of death from disease or last follow-up. The relationship between nonparametric variables was studied by Chi-square test. Parametric variables were compared with independent sample $t$ test. $P$ values below 0.05 were considered to be significant. Survival estimates were calculated by using the Kaplan-Meier method.

\section{RESULTS}

Thirty-four (91.9\%) of the SCLC patients were male, and eleven (73.3\%) of the EPSCC patients were female. When genders were compared in SCLC and EPSCC patients, SCLC was more common in males, however EPSCC was more common in females $(\mathrm{p}=0.001)$. A KRAS mutation was found in $6(16.2 \%)$ SCLC patients, with the most common mutation being the Exon 3 mutation. Only one patient had an Exon 2 mutation. The most common mutation was the Q61R (CAA $>$ CGA) mutation found in 4 patients with an Exon 3 mutation. One patient carried Q61L (CAA $>$ CTA), and 1 patient carried G12C (GGT $>$ TGT). Among the 15 EPSCC patients, 2 had a KRAS mutation (13.3\%). One

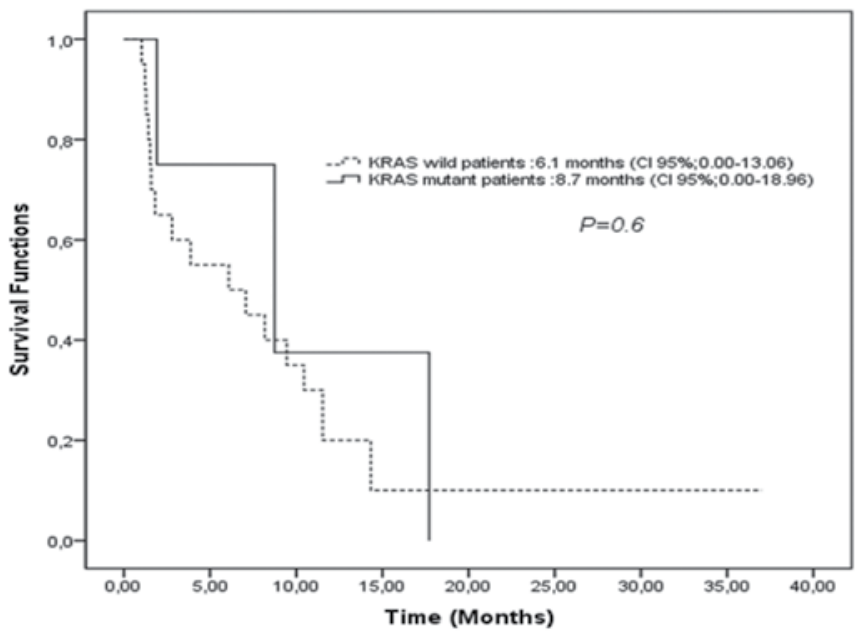

FIG. 1. SCLC overall survivall

patient with pancreatic EPSCC carried the G12D (GGT $>$ GAT) mutation. One patient with prostatic EPSCC carried the Q61L (CAA $>$ CTA) mutation (Table 1). No difference in KRAS mutation status was observed between SCLC and EPSCC patients $(\mathrm{p}=0.8)$. An Exon 3 mutation was found in $80 \%$ of SCLC and $50 \%$ of EPSCC patients. Overall survival was 6.1 months (CI $95 \%$; 0.00-13.06) in KRAS wild type SCLC and 8.7 months (CI $95 \%$; 0.00-18.96) in KRAS mutant SCLC cases. When KRAS mutant and wild type SCLC patients were compared, no difference was found in overall survival $(\mathrm{p}=0.6)$ (Figure 1).

\section{DISCUSSION}

KRAS mutations are present in $12-36 \%$ of lung adenocarcinoma, but are rare in squamous cell lung cancer. In lung adenocarcinoma, KRAS mutations are more common in smokers (12-16). The prognostic significance of KRAS mutations in NSCLC is controversial (17-19). Maitra et al. (20) identified KRAS mutations in $2(17 \%)$ of 12 gallbladder EPSCC patients. In our study, 2 of 15 EPSCC patients had KRAS mutations $(13 \%)$. In their genetic profile study, Wakuda et al. (21) found that $1(1.6 \%)$ of 60 SCLC patients had KRAS mutations; this patient also had adenocarcinoma. In their study on 43 SCLC and 3 EPSCC patients, Yamamoto et al. (22) found that none of the patients had KRAS mutations. In our study, $6(16.2 \%)$ of 37 SCLC patients had KRAS mutations. There were ethnic and geographical differences in the KRAS mutation status of patients with colorectal cancer and NSCLC $(19,23,24)$. Genetic, dietary and environmental factors play a role in the development of KRAS mutations. More than $80 \%$ of KRAS mutations are exon 2 mutations in NSCLC and colorectal cancers $(19,23)$. In our study, $80 \%$ of KRAS mutations in SCLC were in exon 3. 
TABLE 1. Patient characteristics

\begin{tabular}{|c|c|c|c|c|c|}
\hline \multirow[b]{2}{*}{ Age } & \multicolumn{2}{|c|}{$\begin{array}{l}\text { Small cell lung carcinoma } \\
\text { (SCLC) (n: 37) }\end{array}$} & \multicolumn{2}{|c|}{$\begin{array}{l}\text { Extrapulmonary small cell carcinoma } \\
\text { (EPSCC) (n: 15) }\end{array}$} & \multirow[t]{2}{*}{$\mathbf{p}$} \\
\hline & 56 & $(42-72)$ & 60 & $(46-85)$ & \\
\hline \multicolumn{6}{|l|}{ KRAS Status } \\
\hline Wild 31 & $(83.8 \%)$ & 13 & $(86.7 \%)$ & 0.8 & \\
\hline Mutant & 6 & $(16.2 \%)$ & 2 & $(13.3 \%)$ & \\
\hline \multicolumn{6}{|l|}{ Gender } \\
\hline Male & 34 & $(91.9 \%)$ & 4 & $(26.7 \%)$ & 0.001 \\
\hline Female & 3 & $(8.1 \%)$ & 11 & $(73.3 \%)$ & \\
\hline \multicolumn{6}{|l|}{ Primary tumor } \\
\hline Lung & 37 & $(100 \%)$ & - & - & \\
\hline GIS & - & & 5 & $(33.3 \%)$ & \\
\hline GUS & - & & 8 & $(53.3 \%)$ & \\
\hline Breast & - & & 2 & $(13.3 \%)$ & \\
\hline KRAS mutations SCLC & & & KRAS mutations EPSCC & & \\
\hline Codon 61 Q61L (CAA>CTA) & 1 & $(2.7 \%)$ & Codon 61 Q61L (CAA>CTA) & $1(6.6 \%)$ & \\
\hline Codon 61 Q61R (CAA>CGA) & 4 & $(10.8 \%)$ & Codon 12 p.G12D (GGT>GAT) & $1(6.6 \%)$ & \\
\hline Codon 12 p.G12C (GGT>TGT) & 1 & $(2.7 \%)$ & KRAS wild type & $13(86.6 \%)$ & \\
\hline KRAS Wild type & 31 & $(83.7 \%)$ & & & \\
\hline \multicolumn{6}{|c|}{ Extrapulmonary small cell carcinoma tumor location and Kras status } \\
\hline Patients & & & Tumor location & & KRAS status \\
\hline 1. & & & Pancreas & Codon 12 & p.G12D (GGT>GAT) \\
\hline 2. & & & Prostate & Codon 6 & Q61L (CAA>CTA) \\
\hline 3. & & & Pancreas & & Wild type \\
\hline 4. & & & Esophagus & & Wild type \\
\hline 5. & & & Esophagus & & Wild type \\
\hline 6. & & & Bladder & & Wild type \\
\hline 7. & & & Bladder & & Wild type \\
\hline 8. & & & Bladder & & Wild type \\
\hline 9. & & & Cervix & & Wild type \\
\hline 10. & & & Cervix & & Wild type \\
\hline 11. & & & Ovary & & Wild type \\
\hline 12. & & & Gallbladder & & Wild type \\
\hline 13. & & & Endometrium & & Wild type \\
\hline 14. & & & Breast & & Wild type \\
\hline 15. & & & Breast & & Wild type \\
\hline
\end{tabular}

The main limitation of our study is the small number of patients; however, EPSCC are rare tumors. There is no targeted therapy approved for the treatment of small cell carcinoma to date. Knowing KRAS mutational status in these tumors may provide further treatment options. There is also a need for other studies examining the genetic profile of SCLC and EPSCC.
In conclusion, there may be ethnical and geographical differences in KRAS mutations of SCLC as in NSCLC and colorectal cancers. A comparison of the incidence of KRAS mutations in different populations may guide the studies on targeted treatment. KRAS mutations should not be excluded in SCLC. 
Ethics Committee Approval: Ethics committee approval was received for this study from the ethics committee of Trakya University School of Medicine.

\section{Informed Consent: N/A.}

Peer-review: Externally peer-reviewed.

Author contributions: Concept - H.K.; Design - H.K.; Supervision - E.T., İ.Ç.; Resource - B.E., S.U.; Materials - H.T., H.G.; Data Collection and/or Processing - H.K., İ.H.; Analysis and/or Interpretation - H.K., B.D.; Literature Search - H.K., E.T.; Writing - H.K.; Critical Reviews - İ.Ç., H.K.

Conflict of Interest: No conflict of interest was declared by the authors.

Financial Disclosure: The authors declared that this study has received no financial support.

\section{REFERENCES}

1. Siegel RL, Sahar L, Portier KM, Ward EM, Jemal A. Cancer statistics, 2015. CA Cancer J Clin 2015;65:5-29. [Crossref]

2. Rosell R, Carcereny E, Gervais R, Vergnenegre A, Massuti B, Felip E, et al. Erlotinib versus standard chemotherapy as firstline treatment for European patients with advanced EGFR mutation-positive non-small-cell lung cancer (EURTAC): a multicentre, open-label, randomised phase 3 trial. Lancet Oncol 2012;13:239-46. [Crossref]

3. Kwak EL, Bang YJ, Camidge DR, Shaw AT, Solomon B, Maki RG, et al. N Engl J Med 2010;363:1693-703. [Crossref]

4. Chute JP, Chen T, Feigal E, Simon R, Johnson BE. Twenty years of phase III trials for patients with extensive-stage small-cell lung cancer: perceptible progress. J Clin Oncol 1999;17:1794801.

5. Sher T, Dy GK, Adjei AA. Small cell lung cancer. Mayo Clin Proc 2008;83:355-67. [Crossref]

6. Jackman DM, Johnson BE. Small-cell lung cancer. Lancet 2005;366:1385-96. [Crossref]

7. Wong YN, Jack RH, Mak V, Henrik M, Davies EA. The epidemiology and survival of extrapulmonary small cell carcinoma in South East England, 1970-2004. BMC Cancer 2009;9:209. [Crossref]

8. Arrington AK, Heinrich EL, Lee W, Duldulao M, Patel S, Sanchez J, et al. Prognostic and predictive roles of KRAS mutation in colorectal cancer. Int J Mol Sci 2012;13:12153-68. [Crossref]

9. Bamford S, Dawson E, Forbes S, Clements J, Pettett R, Dogan A, et al. The COSMIC (Catalogue of Somatic Mutations in Cancer) database and website. Br J Cancer 2004;91:355-8. [Crossref]
10. Cicin I, Usta U, Karagol H, Uzunoglu S, Kocak Z. Extrapulmonary small cell carcinoma localized in lymph nodes: is it a different clinical entity? Acta Oncol 2009;48:354-60. [Crossref]

11. Cicin I, Karagol H, Uzunoglu S, Uygun K, Usta U, Kocak Z, et al. Extrapulmonary small-cell carcinoma compared with smallcell lung carcinoma: a retrospective single-center study. Cancer 2007;110:1068-76. [Crossref]

12. Riely GJ, Kris MG, Rosenbaum D, Marks J, Li A, Chitale DA, et al. Frequency and distinctive spectrum of KRAS mutations in never smokers with lung adenocarcinoma. Clin Cancer Res 2008; 14:5731-4. [Crossref]

13. Seo JS, Ju YS, Lee WC, Shin JY, Lee JK, Bleazard T, et al. The transcriptional landscape and mutational profile of lung adenocarcinoma. Genome Res 2012;22:2109-19. [Crossref]

14. Sos ML, Thomas RK. Genetic insight and therapeutic targets in squamous-cell lung cancer. Oncogene 2012;31:4811-4. [Crossref]

15. Brose MS, Volpe P, Feldman M, Kumar M, Rishi I, Gerrero R, et al. BRAF and RAS mutations in human lung cancer and melanoma. Cancer Res 2002;62:6997-7000.

16. Couraud S, Zalcman G, Milleron B, Morin F, Souquet PJ. Lung cancer in never smokers--a review. Eur J Cancer 2012;48:1299311. [Crossref]

17. Karachaliou N, Mayo C, Costa C, Magri I, Gimenez-Capitan A, Molina-Vila MA, et al. Clin Lung Cancer 2013;14:205-14. [Crossref]

18. Shepherd FA, Domerg C, Hainaut P, Janne PA, Pignon JP, Graziano S, et al. Pooled analysis of the prognostic and predictive effects of KRAS mutation status and KRAS mutation subtype in earlystage resected non-small-cell lung cancer in four trials of adjuvant chemotherapy. J Clin Oncol 2013;31:2173-81. [Crossref]

19. Smits AJ, Kummer JA, Hinrichs JW, Herder GJ, Scheidel-Jacobse $\mathrm{KC}$, Jiwa NM, et al. EGFR and KRAS mutations in lung carcinomas in the Dutch population: increased EGFR mutation frequency in malignant pleural effusion of lung adenocarcinoma. Cell Oncol (Dordr) 2012;35:189-96. [Crossref]

20. Maitra A, Tascilar M, Hruban RH, Offerhaus GJ, Albores-Saavedra J. Small cell carcinoma of the gallbladder: a clinicopathologic, immunohistochemical, and molecular pathology study of 12 cases. Am J Surg Pathol 2001;25:595-601. [Crossref]

21. Wakuda K, Kenmotsu H, Serizawa M, Koh Y, Isaka M, Takahashi S, et al. Molecular profiling of small cell lung cancer in a Japanese cohort. Lung Cancer 2014;84:139-44. [Crossref]

22. Yamamoto H, Shigematsu H, Nomura M, Lockwood WW, Sato M, Okumura N, et al. PIK3CA mutations and copy number gains in human lung cancers. Cancer Res 2008;68:6913-21. [Crossref]

23. Kodaz H, Hacibekiroglu I, Erdogan B, Turkmen E, Tozkir H, Albayrak D, et al. Association between specific KRAS mutations and the clinicopathological characteristics of colorectal tumors. Mol Clin Oncol 2015;3:179-84.

24. Murtaza BN, Bibi A, Rashid MU, Khan YI, Chaudri MS, Shakoori AR. Spectrum of K ras mutations in Pakistani colorectal cancer patients. Braz J Med Biol Res 2014;47:35-41. [Crossref] 